\title{
Determinants of Inter-Firm Trust in a Tourism Region
}

\author{
Nguyen Phuc Nguyen ${ }^{1}$ \\ ${ }^{1}$ University of Economics-The University of Danang, Vietnam \\ Correspondence: Nguyen Phuc Nguyen, University of Economics-The University of Danang, Vietnam. Tel: \\ 84-511-395-0475. E-mail: nguyennp@ud.edu.vn
}

Received: April 27, 2015

Accepted: May 5, 2015

Online Published: May 22, 2015

doi:10.5539/ijbm.v10n6p134

URL: http://dx.doi.org/10.5539/ijbm.v10n6p134

\begin{abstract}
Many scholars hold that trust is one of the key in searching for inter-firm cooperation. But there are few studies to investigate the antecedent of inter-firm trust. The aim of the research is to identify the main determinants of inter-firm trust in tourism region. With an empirical study of 262 enterprises in a tourism region in Vietnam, the study finds that characteristics of firms and its executives do significantly positively affect inter-firm trust. The result also reveals that communication and sharing information, using social network in inter-firm relationship will facilitate trust between partners. The result support the general thesis that executive can build and develop inter-firm trust based on its main determinants. The study provides both theoretical and practical implications.
\end{abstract}

Keywords: trust, inter-firm relationship, tourism, social network, Vietnam

\section{Introduction}

Many inter-firm alliances have experienced the failure over time (Bamford et al., 2004; Pak et al., 2009). A lack of trust is an often-cited reason for why business relationship fails to develop and leads to the ultimate dissolution of inter-firm cooperation (Buchel, 2003). Moreover, scholar have highlighted the importance of trust as a means of establishing and sustaining inter-firm cooperation (Lui et al., 2006; Morgan \& Hunt, 1994; Pesämaa \& Hair, 2007).

Many studies have been devoted to examine the nature of trust from psychology (Rotter, 1967), social theory (Zucker, 1986) to marketing and management (Anderson \& Narus, 1990; Zaheer et al., 1998). Trust is divided into three types: inter-organizational trust, agency trust and personal trust (Fang et al., 2008; Zaheer et al., 1998). Moreover, the study of trust may be categorized based on how trust is viewed and composed: as an individual characteristic, as partner characteristics, as an characteristic of interpersonal transaction, and as an institutional phenomenon (Bhattacharya et al., 1998; Doney \& Cannon, 1997; Ganesan, 1994; Kwon \& Suh, 2004; Moorman et al., 1993; Zucker, 1986). The others, on the other hand, found the way to build trust (Nguyen \& Rose, 2009; Nguyen \& Liem, 2013).

It is clear that, in spite of the importance of trust and the increased interest among researchers, there are gaps in theory on trust in two ways. Firstly, although trust can be engendered from organization, its representative or circumstances, most of the emphasis is at one or both targets, not all (e.g. Doney \& Canon, 1997; Kennedy et al., 2001; Moorman et al., 1993; Nguyen \& Rose, 2009). Secondly, the review of inter-firm trust has been investigated in detail from the work of Nguyen \& Liem (2013). It is important to understand which factors influence trust in inter-firm relationship especially for tourism region. Lastly, the relationship between trust and external forces such as institutional effect has rarely studied especially in developing country.

To address these shortcomings delineated above, this paper presents a model of antecedents of inter-firm trust based on previous studies. In the following, the author first provides a brief overview of the literature on trust. Then he develops hypotheses and builds the conceptual model. The model is tested by data sourced from the survey of Vietnamese enterprises in tourism region. The paper concludes with a discussion of findings and its implication for both academic research and business practice.

\section{Theoretical background}

\subsection{Trust Concept}

Trust can be defined differently from many disciplines. In psychology, trust is an expectancy held by an individual or a group that the word, promise, verbal or written statement of another individual or group can be 
relied upon (Rotter, 1967). In sociality theory, trust is a set of expectations shared by all those involved in an exchange (Zucker, 1986) or a bet about the future contingent actions of others (Sztompka, 2003). It has been used and extended into organizational level by management scholars (Doney \& Cannon, 1997; Morgan \& Hunt, 1994). In this paper, the author uses trust's definition of Nguyen and Liem (2013), "trust as the expectation held by a party toward another party or objects that the trustee will behave in a predictable manner, not exploit the other's vulnerability in case of opportunism".

\subsection{Characteristics of Trust}

Based on the definitions of trust, we can infer three characteristics of trust.

- The first characteristic of trust is risk. Trust associates with risk. Without uncertainty environment or risk, trust is no meaning (Bhattacharya et al., 1998). In inter-firm relationships, there always consists of opportunism, in which one partner can take advantages from other. We trust somebody or something means that we travel with risk for betting about uncertain future (Sztompka, 2003; Young-Ybarra \& Wiersema, 1999; Zaheer et al., 1998).

- The second characteristics relates to vulnerability. Trust is context based. As the result of risky environment where trust is located, the actor is being vulnerable situation. Based on the confidence in another will, the partner hopes that the other will not take chances even if there is incentive for it (Curral \& Inkpen, 2002; Dyer \& Chu, 2000; McKnight et al., 1998).

- Trust ties to the expectation. The expectation is based on the credibility on the other party's competency or expertise to fulfil his/her obligation. The expectation requires benevolence from current party who will care about other's welfare or act in the alliance's best interest (Ganesan \& Hess, 1997; Nguyen \& Liem, 2013; Rosseau et al., 1998)

\subsection{The Level of Trust}

In general, there are three distinct levels of trust (Curral \& Inkpen, 2002; Fang et al., 2008; Gassenheimer \& Manolis, 2001; Lui et al., 2006).

- Inter-firm trust (or collaborating mutual trust). This is trust between firms in a relationship.

- Agency trust refers to each firm's agency trust in its representatives assigned to the inter-firm relationship

- Intraentity trust (interpersonal trust) refers to trust between representatives of collaborating organizations or between two people in.

Trust can be classified and viewed differently due to the context. This paper therefore attempts to advance theory and practice by examining factors that influence trust between firms. The empirical study of inter-firm trust in tourism region will be discussed.

\section{Hypothesis}

\subsection{The Effect of Subject's Characteristics on Trust}

Trust is closely related to basic norms of behavior and social customs in which most actors take it for granted until it is violated. Company and its representatives (the managers) are subjects in inter-firm relationships. These subjects affect trust through their attributes in a number of ways. Knoll and Gill (2011) demonstrated that trust in the trustee is a function of trustee's perceived ability. On the one hand, for instance, the reputation of a company could provide an extra assurance for committed people to deal with social uncertainty in the deals with outsiders (Yamagishi \& Yamaghishi, 1994). Previous study asserted that firm characteristics affect executives' strategic decision making process or managerial discretion (Finkelstein \& Hambrick, 1990). Particularly, firm size and age have been found to be especially important factors in shaping managerial decision making as well as inter-firm trust (Shinkle \& Kriauciunas, 2010; Nguyen, 2011). On the other hand, Jiang et al. (2011) proposed the negative effect of relative firm size on executives' cognition-based trust in their partners. In inter-firm relationship, it is expected that the preeminent characteristics of one firm will enhance the chance for this relations from other partner because it does not need to validate the reliability and competence of the previous.

Hypothesis 1: There is positive relationship between company's characteristics and inter-firm trust. The more superior characteristics of business partner is associated with greater trust that one partner places in another.

In another side, the reliability and capability of the suppliers will deliver the most important promises to their distributors and will create trust and a continued association with them (Tuang \& Stringer, 2008). Similarity, Gill et al. (2005) found the positive relationship between ability of trustor and trust located in trustee. In addition, competency of salesperson would create buyer's trust (Kennedy et al., 2001). On the other hand, Zucker (1986) and Jiang et al. (2011) asserted that trust is related to characteristics or competency of partners. Further, Nguyen 
and Liem (2013) proposed that attributes of trading partner (skills, competence, and characteristics) offer room for influencing another trading partner. In addition, competence and reputation in an important foundation of trust (Moorman et al., 1993). Based on these, it is expected that:

Hypothesis 2: There is positive relationship between company's manager attributes and trust. The more superior characteristics of partner's representative is associated with greater trust that one partner places in another.

\subsection{The Effect of Institutions on Trust}

Attributes of subjects are not the only factor affecting trust. There is good reason to believe that institutions influence trust between actors. In her research, Zucker (1986) mentioned about institution based trust. Hardin (1996) argued that "our institutions enhance trustworthiness". Institutions consist of formal institution (political rules, regulation, and economic contract) and informal institution (social sanctions). One might highlight three ways in which institutions are likely to affect trust between actors. Firstly, because "social institutions are sets of rules that structure social interactions in particular ways" (Knight, 1992), it will mandate that information about how actors behave is shared among members of a particular community. Institutions are "the rule of the game" (North, 1990). Such rules may enhance trust between partners. Moreover, trustworthy behaviour between firms can be facilitated by institutions (Zucker, 1986). Secondly, institutions will direct actors toward predictable behavior due to the afraid of the threat of sanctions in the event of noncompliance (Knight, 1992; Nguyen \& Rose, 2009; Nguyen \& Liem, 2013). Finally, institutions (formal and informal) are channel to provide information as the past behavior of actors. This information will help manager learn more about partner and enhance trust between them as the result. Thus, it is expected that:

Hypothesis 3: The greater use of formal institution in making inter-firm relationship is associated with greater trust that one partner places in another.

Executives can use social network to build inter-firm trust with their partner as the role of informal institutions (Hoang \& Antoncic, 2003; Nguyen \& Rose, 2009). Firstly, trustworthy behavior between firms can be developed in an open social networks, where member can learn about each other. Secondly, social network with its own rules of acceptable behaviors will shape inter-firm relationship. The personal relationship that a manger had with his suppliers' manager was very pronounced and their trust was tied to the individuals they dealt with (Tuang \& Stringer, 2008). Thirdly, trust can be transitive among members in a social networks (Nguyen \& Rose, 2009). If both parties trust a third person, this person will share similar sets of values among them and facilitate trust with each other. Based on the above discussion, the author argues that:

Hypothesis 4: The greater use of social network in making inter-firm relationship is associated with greater trust that one partner places in another.

\subsection{The Effect of Communication and Information Sharing on Trust}

Yet another line of research concerning interaction between actors can be viewed as involving trust: communication in inter-firm relationships. Communication is defined as "the formal and informal sharing of credible and meaningful and timely information between exchange partners" (Anderson \& Narus, 1990). This also is called process based trust (Zucker, 1986). Communication affects trust between partners in several ways. On the one hand, past communication can be viewed as an antecedent of trust (Morgan \& Hunt, 1994). On the other hand, information sharing or information symmetries may reduce partner behavioral uncertainty (Dyer \& $\mathrm{Chu}, 2000)$. It can be interpreted as a sign of trust within inter-firm relationship. Overall, the idea of trust emerging with frequently communication is based on the premise that through on-going interaction, parties learn about each other and develop trust (Shapiro et al., 1992).

The extant empirical studies also demonstrated the positive linkage from communication to trust. For instance, Kwon and Suh (2004) reported a significant impact of communication on supply chain partner's trust. Doney and Cannon (1997) emphasized the need of communication (frequency and length of business contact) in building trust. This fact also got strong support from study of Ganesan (1994) and Morgan and Hunt (1990). Tuang and Stringer (2008) revealed that quality communication and effective information exchange are crucial factor in developing inter-firm relationship. Thus, it is expected that:

Hypothesis 5: The more and frequently communication as well as information sharing between partners and its representatives, the greater trust that one partner places in the other.

\section{Research Method}

\subsection{Data Collection}

We conduct the survey in order to evaluate the crucial factors influencing trust and their respective importance. 
The conceptual definitions of construct were adopted from the literature. The study has used multi-item scale to operationalize independent and dependent variables. All items were measured using a Likert-type scale of 7 point where 1 means "Strongly disagree" and 7 "Strongly agree". Table 1 presents the bibliographical sources taken as reference to build the constructs. To build the questionnaire, the original English version of the items was translated into Vietnamese and back translated into English to ensure clarity (Brislin, 1970; Venkatesh et al., 2012).

A pilot survey (with 50 answers) was conducted in May 2014 in order to refine the questionnaires and gain additional comments on the content and appearance. The most important change was in items belongs to formal institutions which was from Aulakh et al. (1996), Nguyen and Rose (2009). After a further review, the questionnaire was deemed ready to be sent to a large sample in order to gather data for testing proposed hypotheses in the study. An introductory participation-request letter along with the questionnaire and a postage-paid reply envelope were sent to a random sample of 600 firms and hotels in tourism region along the central coast of Vietnam. The survey was carried from July 2014 to September 2014. An initial follow-up telephone call is made to non-respondents 4 weeks after the questionnaires were sent. Approximately 4 weeks after the first follow-up, non-respondents were telephoned as a reminder. In total of 276 received questionnaires, 262 responses were validated for using hypothesis testing.

Table 1. Bibliographical sources for item developed

\begin{tabular}{|c|c|}
\hline Construct & Bibliographical sources \\
\hline Company characteristics (Company: 5 items) & $\begin{array}{l}\text { Cerri Shpëtim, 2012; Doney and Cannon, 1997; Lui et al., 2006; } \\
\text { Jiang et al., 2011; Svensson, } 2001\end{array}$ \\
\hline Executives characteristics (Executive: 5 items) & $\begin{array}{l}\text { Anderson and Weitz, 1989; Doney and Cannon, 1997; } \\
\text { Gassenheimer and Manolis, 2001; Kennedy et al., 2001; Moorman } \\
\text { et al., 1993; Jiang et al., } 2011\end{array}$ \\
\hline Use of formal institutions (Formal_institutions: 4 items) & Aulakh et al., 1996; Lee et al., 2001; Nguyen and Rose, 2009 \\
\hline Use of social network (Social_network: 5 items) & Nguyen and Rose, 2009; Cerri Shpëtim, 2012 \\
\hline $\begin{array}{l}\text { Communication and information sharing (Communication: } 4 \\
\text { items) }\end{array}$ & $\begin{array}{l}\text { Cerri Shpëtim, 2012; Coote et al., 2003; Mohr and Spekman 1994; } \\
\text { Young-Ybarra et al., } 1999\end{array}$ \\
\hline Inter-firm trust (Trust: 6 items) & $\begin{array}{l}\text { Coote et al., 2003; Fang et al., 2008; Gassenheimer and Manolis } \\
\text { 2001; Kennedy et al., 2001; Mohr and Spekman, 1994; Svensson, } \\
2001\end{array}$ \\
\hline
\end{tabular}

From the survey, the majority of participating firms are small size that has less than 200 full-time employees covers $68.65 \%$ of the survey (medium size: $20.21 \%$ and large size: $11.14 \%$ ). Moreover, about more than half of the formal enterprises originated from private sector and are relatively young (less than 9 years of operation).

\subsection{Measures}

\subsubsection{Dependent Variable}

Based on its abstract characteristics, individuals and firms use indirect measures- indices or signals to measure trust (Zucker, 1986). Therefore, inter-firm trust measures, denoted by Trust, were adapted from previous studies (Coote et al., 2003; Fang et al., 2008; Svensson, 2001). The scales measured trust in which manager placed in the cooperative firm and in the cooperative firm's representatives as well. The six items give a reliable with a single factor and a Cronbach's alpha of 0.90

\subsubsection{Independent Variables}

\section{Company characteristics (Company)}

Company attributes refer to company characteristics, which influence partner's behavior indirectly through trust. Company attributes were measured using scale from Cerri Shpëtim (2012), Doney and Cannon (1997), Lui et al. (2006), Jiang et al. (2011) and Svensson (2001). The scale has five items on a 7-point scale and had a reliability (alpha) coefficient of 0.89

\section{Executive characteristics (Executive)}

Representative attributes refer to the characteristics of the manager, who represents for company in making inter-firm relationships with its partner. Five items, which are adapted and modified from existing literature (Gassenheimer \& Manolis, 2001; Kennedy et al., 2001; Mayer et al., 1995), were used to measure this construct. 
This measure displays good reliability (alpha $=0.91$ )

\section{The use of formal institutions (Formal_institution)}

Another variable of interest was the use of formal institutions. This is one of strategies that can be used to build trust in the study of Nguyen and Rose (2009). The study adapted their scale in combining with the scale of Aulakh et al. (1996) and Lee et al. (2001) to measure this construct. The reliability of the use of formal institution in this study was 0.85

\section{The use of social network (Social_network)}

The research also used two items in Nguyen and Rose (2009) and three items from Cerri (2012) to measure the use of social network in building trust between firms. This measure has high reliability (alpha $=0.87$ ).

\section{Communication and information sharing (Communication)}

The last factor, which influences inter-firm trust, is communication between executives as well as firms. This construct reflects business information sharing and any method used in order to get better understanding between target partners. Four items adapted from Cerri (2012), Coote et al. (2003), Mohr and Spekman (1994), and Young-Ybarra et al. (1999) were used to measure this construct. The Cronbach's alpha for this measure is 0.85

\subsubsection{Control Variables}

The study also included two control variables in the analyses. The first control variable relates to age of company with the expectation that the longer the company exists, the more it is known, and more trust ties to it (Cerri, 2012; Nguyen \& Rose, 2009). This variable has value range from 1 to 4 indicating four levels: less than 5 years, from 5 to 9 years, from 10 to 15 years and more than 15 years of business. The second one includes the ownership difference. The dummy variables, which value 1 if firm is owned by specific subject (state, private or foreign owned) are added, respectively. Executives of particular type of ownership likely have different objectives and attitudes toward inter-firm relationship (Nguyen \& Rose, 2009).

\subsection{Econometric Model}

The econometric model, which is used to analyze the impact of trust antecedents, is given by the following equation.

$$
\begin{aligned}
& \text { Trust }=\beta_{0}+\beta_{1} \text { Company }+\beta_{2} \text { Executive }+\beta_{3} \text { Formal_institution } \\
& +\beta_{4} \text { Social_network }+\beta_{5} \text { Communication }+\beta_{6} \text { Control }+\varepsilon
\end{aligned}
$$

Where Trust is trust that one company places in its particular partner; Company is the vector of company's attributes; Executive is the vector of executive's characteristics; Formal_institution is a formal institutional effect; Social_network is the effect of the use of informal social network; Communication is the effect of information sharing and communication between partners; Control is a vector of control variables; $\varepsilon$ is the error term.

\section{Empirical Results}

\subsection{Common Method Variance}

Two important issues have been raised concerning the survey methodology: common method variance and non-response bias problem. To assess the possibility of common method variance, the study used Harman's post hoc single-factor test (Podsakoff \& Organ, 1986). If common method variance appears in the study, it would be expected that a single factor emerging from a factor analysis or one general factor to account for the majority of the variance. All the variables of interest were entered into factor analysis. Six factors were extracted and account for $76.34 \%$ of the variance. The first factor accounts for the highest proportion of variance, but only at $33.67 \%$. Because the first factor (the highest variance explanation) did not account for the majority of the variance in those distinct factors, the author can conclude that the common method variance does not appear to be a problem in the study.

As recommend by Armstrong and Overton (1977), potential non-response bias was assessed via extrapolation method of comparing early versus late respondents. Firstly, a comparison of early to late responses revealed no difference with regard to the means of all variables, especially on company's age and size. Secondly, an analysis of ownership distribution of the respondents shows no difference from the ownership distribution of all the firms and hotels used in the survey. Therefore, the non-response bias was minimal.

\subsection{Confirmatory Factor Analysis}

The study uses two-step approach to test the proposed model. This study first conducts a confirmatory factor analysis with maximum likelihood to test measurement model by verifying the underlying structure of constructs. 
Then the OLS regression with trust as dependent variables and its antecedents as independent variables is used to test research hypotheses.

The model specification proposed was subject to confirmatory factor analysis, which was performed using LISREL 8.80 to assess construct validity and convergent validity. In this study, all the variables were latent since they were not directly observable. Thus, the author used instrument measurement as proxies that works as indicators of the latent constructs. Table 2 provides the results of the measurement analysis.

Table 2. Results from the confirmatory factor analysis

\begin{tabular}{|c|c|c|c|c|c|}
\hline Constructs & Items & $\begin{array}{l}\text { Construct } \\
\text { reliability (CR) }\end{array}$ & (AVE) & S.T. Loadings & t-value \\
\hline \multirow[t]{5}{*}{ Company characteristics } & 1 & 0.89 & 0.61 & 0.785 & 10.524 \\
\hline & 2 & & & 0.844 & 14.342 \\
\hline & 3 & & & 0.708 & 10.678 \\
\hline & 4 & & & 0.757 & 10.446 \\
\hline & 5 & & & 0.808 & 14.125 \\
\hline \multirow[t]{5}{*}{ Executive characteristics } & 1 & 0.91 & 0.67 & 0.743 & 12.961 \\
\hline & 2 & & & 0.839 & 14.462 \\
\hline & 3 & & & 0.891 & 14.732 \\
\hline & 4 & & & 0.845 & 14.808 \\
\hline & 5 & & & 0.751 & 13.121 \\
\hline \multirow[t]{4}{*}{ Formal institutions } & 1 & 0.85 & 0.58 & 0.757 & 11.950 \\
\hline & 2 & & & 0.691 & 10.270 \\
\hline & 3 & & & 0.826 & 15.678 \\
\hline & 4 & & & 0.764 & 14.449 \\
\hline \multirow[t]{5}{*}{ Social network } & 1 & 0.87 & 0.58 & 0.876 & 14.941 \\
\hline & 2 & & & 0.771 & 12.401 \\
\hline & 3 & & & 0.741 & 11.723 \\
\hline & 4 & & & 0.704 & 10.950 \\
\hline & 5 & & & 0.689 & 10.686 \\
\hline \multirow[t]{4}{*}{ Communication } & 1 & 0.85 & 0.59 & 0.782 & 12.211 \\
\hline & 2 & & & 0.732 & 11.158 \\
\hline & 3 & & & 0.818 & 12.959 \\
\hline & 4 & & & 0.726 & 10.920 \\
\hline \multirow[t]{6}{*}{ Trust } & 1 & 0.90 & 0.59 & 0.731 & 12.055 \\
\hline & 2 & & & 0.725 & 11.422 \\
\hline & 3 & & & 0.701 & 11.240 \\
\hline & 4 & & & 0.824 & 15.203 \\
\hline & 5 & & & 0.763 & 12.637 \\
\hline & 6 & & & 0.868 & 15.473 \\
\hline
\end{tabular}

Note: $A V E=\sum_{i=1}^{n} \lambda_{i}^{2} / n$ where $\lambda$ represents the standardized factor loading in CFA and $n$ is the number of items.

where $\delta$ is the error variance for an item.

$$
C R=\left(\sum_{i=1}^{n} \lambda_{i}\right)^{2} /\left[\left(\sum_{i=1}^{n} \lambda_{i}\right)^{2}+\left(\sum_{i=1}^{n} \delta_{i}\right)\right]
$$

The chi-square of the measurement model was significant $\left(\chi^{2}=689.24, d f=321, p<0.001\right)$, with the value of $\left(\chi^{2} / d f=2.15\right)$ is below the recommended cutoff of 5.0, indicating an ideal fit (Schumacker \& Lomax, 2004). The large chi-square value was not suspiring, because the chi-square statistic has proven to be directly affected by sample size (Chen et al., 2008). Therefore, in order to assess the overall model fit, alternative stand-alone fit indices, which are less sensitive to sample size, were used. These indices included the comparative fit index (CFI), the root mean square error of approximation (RMSEA), the normed fit index (NFI), and the non-normed 
fit index (NNFI). Based on Hair et al (2009), the six factor model show a good model fit ( $\mathrm{CFI}=0.95$; RMSEA $=0.06$; NFI $=0.92 ; \mathrm{NNFI}=0.94$ ).

Convergent validity is attained if the items that are indicators of a specific construct converge or share a high proportion of variance. There are three methods to examine convergent validity. First, standardized loading estimates should be 0.5 or higher and ideally over 0.7 . From Table 2 , all loadings are significant $(p<.001)$ and above 0.5 , only two was below 0.7 . Thus, the measurement model passes this test. Second, the average percentage of variance extracted (AVE) should be higher 0.5 , suggesting adequate convergence. The values of AVEs are greater than 0.5 in all cases, meaning that the variance accounted for by each construct is greater than the variance accounted for by measurement error (Fornell \& Larcker, 1981). Last, to assess the reliability of the construct, construct reliability (CR) is used. All construct reliability values, ranging from 0.85 to 0.91 , meet the recommended cut-off value of 0.80 (Fornell \& Larcker, 1981), ensuring adequate internal consistence of multiple items of each construct (Hair et al., 2009). This result suggests that the measurement model has good convergent validity.

To assess discriminant validity of measurement model, the study uses the procedure developed by Fornell and Larcker (1981). It involves the calculation of the average variance extracted for all pair of constructs. These values must be compared with squared correlations between any pair of constructs of interest and be greater if discriminant validity is present. The data passed this test too and therefore discriminant validity is confirmed. Based on this foundation, the measurement model fits the data well (Table 3).

Table 3. Discriminant validity in measurement model

\begin{tabular}{lllllll}
\hline Constructs & $\mathbf{1}$ & $\mathbf{2}$ & $\mathbf{3}$ & $\mathbf{4}$ & $\mathbf{5}$ & $\mathbf{6}$ \\
\hline Inter-firm trust (1) & 0.59 & & & & & \\
Company characteristics (2) & 0.38 & 0.61 & & & & \\
Executive characteristics (3) & 0.47 & 0.29 & 0.67 & & & \\
Use of formal institutions (4) & 0.16 & 0.07 & 0.07 & 0.58 & & \\
Use of social network (5) & 0.42 & 0.19 & 0.43 & 0.09 & 0.58 & \\
Communication \& Information sharing (6) & 0.50 & 0.32 & 0.48 & 0.01 & 0.24 & 0.59 \\
\hline
\end{tabular}

Note. The AVE's are on the diagonal, and the squared coefficients between construct are below the diagonal.

\subsection{Regression Analysis and Hypotheses Test}

Table 4 presents the descriptive statistics and the correlation matrix for the variable set of the study. The dummy variable (Public owned firms or hotels) is excluded as a base. Because the data were cross-sectional, with evidence of correlation between some predictor variables, multicollinearity will be tested by variance inflation factor (VIF) indices. According Hair et al. (2009), there are two methods of detecting multicollinearity problem: one relates to correlation coefficient and the other is checking VIFs. The correlation between any two variables is below 0.7 and the largest VIF also is under 2.0. It was concluded that multicollinearity was not a serious issue in this study (Hair et al., 2009).

Table 4. Descriptive statistics and VIF of variables

\begin{tabular}{|c|c|c|c|c|c|c|c|c|c|c|c|}
\hline Variable & Mean & S.D. & 1 & 2 & 3 & 4 & 5 & 6 & 7 & 8 & 9 \\
\hline Trust (1) & 4.82 & 1.00 & 1.00 & & & & & & & & \\
\hline Company characteristics (2) & 4.70 & 1.10 & $0.40 * *$ & 1.00 & & & & & & & \\
\hline Executive characteristics (3) & 4.93 & 1.06 & $0.42 * *$ & $0.40^{*}$ & 1.00 & & & & & & \\
\hline Use of formal institutions (4) & 3.72 & 1.15 & $0.25^{*}$ & 0.14 & $0.10^{*}$ & 1.00 & & & & & \\
\hline Use of social network (5) & 5.74 & 1.19 & $0.45^{* *}$ & 0.40 & $0.48 * *$ & $-0.24 *$ & 1.00 & & & & \\
\hline $\begin{array}{l}\text { Communication and information } \\
\text { sharing (6) }\end{array}$ & 4.49 & 1.09 & $0.54^{* *}$ & 0.49 & $0.44^{* *}$ & 0.12 & $0.42 * *$ & 1.00 & & & \\
\hline Age of firm (7) & 2.50 & 1.10 & -0.08 & $0.11 *$ & 0.09 & $0.17 * *$ & 0.05 & 0.03 & 1.00 & & \\
\hline Private firm (8) & 0.62 & 0.51 & $0.19 *$ & -0.00 & 0.07 & -0.03 & $0.21 * *$ & $0.02 *$ & 0.04 & 1.00 & \\
\hline Foreign firm (9) & 0.26 & 0.38 & $0.07 *$ & 0.08 & $0.04 *$ & $0.11 *$ & -0.03 & 0.03 & -0.10 & -0.32 & 1.00 \\
\hline
\end{tabular}

Note. Correlation is significant at $* * \mathrm{p}<0.01, * \mathrm{p}<0.05$ (2-tailed).

To test research hypotheses, the study estimates an OLS-regression model incorporating the effect of company 
attributes, representative attributes, the use of formal institutions, the use of social network, and communication on trust. The study includes age of company and regional difference in the model as control variables. Table 5 gives the estimated parameters of the model.

Table 5. Regression results

\begin{tabular}{|c|c|c|c|c|}
\hline & Case 1 & Case 2 & Case 3 & Case 4 \\
\hline Variables & Trust & Trust & Trust & Trust \\
\hline Company & $0.132 *$ & $0.128 *$ & $0.125^{*}$ & $0.131 *$ \\
\hline Executive & $0.181^{* *}$ & $0.175 * *$ & $0.174 * *$ & $0.175 * *$ \\
\hline Formal_institutions & $0.037 *$ & $0.021 *$ & $0.028 *$ & $0.019 *$ \\
\hline Social_network & $0.321 * *$ & $0.378 * *$ & $0.327 * * *$ & $0.315^{* * *}$ \\
\hline Communication & $0.261 * * *$ & $0.258 * * *$ & $0.248 * * *$ & $0.234 * * *$ \\
\hline Age & & -0.069 & -0.085 & -0.042 \\
\hline Private & & & $0.059^{*}$ & $0.046 *$ \\
\hline Foreign & & & 0.023 & $0.037 *$ \\
\hline Constant & $0.809 * *$ & $1.024 * *$ & $1.077 * *$ & $1.149 * *$ \\
\hline Adjusted $\mathrm{R}^{2}$ & 0.342 & 0.336 & 0.328 & 0.312 \\
\hline $\mathrm{F}$ & $19.48 * * *$ & $16.26 * * *$ & $15.36^{* * *}$ & $12.37 * * *$ \\
\hline Observations & 262 & 262 & 262 & 262 \\
\hline
\end{tabular}

Note. $* * * \mathrm{p}<0.01, * * \mathrm{p}<0.05, * \mathrm{p}<0.1$.

The overall goodness of fit for the initial model (model without control variables-Case 1) and control models (Case 2, Case 3 and Case 4$)$ are acceptable $\left(p<0.01\right.$ in all cases); $R_{A d j}^{2}=0.342$ (Case 1$), R_{A d j}^{2}=0.336($ Case 2), $R_{A d j}^{2}=0.328$ (Case 3), and $R_{A d j}^{2}=0.312$ (Case 4). These indices indicate that the model shows an adequate description of the study data set. Some studies have reported higher levels of explained variance (e.g. Adobor, 2005; Nguyen and Rose, 2009). The others, on the other hand, have reported lower levels (e.g. Coulter and Coulter, 2002; Sako and Helper, 1998). Thus, an $R_{A d j}^{2}$ of $31 \%$ of the study is within the range reported in the current literature.

Hypothesis 1 contends that there is a positive relationship between company attributes and trust among partners. The coefficient is strong and significant for all cases indicating that company characteristics has a strong positive association with inter-firm trust. Hence, hypothesis 1 receives significant support from empirical results.

Hypothesis 2 states that executive's characteristics do influence trust between firms. This hypothesis was supported $(\beta=0.181, p<0.05)$. These findings are in line with trust-based characteristics of Zucker (1986), which proposes that characteristics of subjects influence trust between them.

Hypotheses 3, 4, and 5 were strongly supported. A moderate positive correlation was found between trust and the use of formal institutions, the use of social network, and communication and information sharing between partners, indicating that a substantial relationship exists between variables, respectively. The regression results revealed the association positive relationship between the use of formal institutions and trust $(\beta=0.037)$. Thus, hypothesis 3 is accepted.

Hypothesis 4 asserts that the more the use of social network, the higher trust will become. This relationship was found to be positive and strong. Among the main determinants of inter-firm trust, using social network affect trustworthy behavior most. Similarity, communication and information sharing had positive and significant coefficient with trust $(\beta=0.261, p<0.05)$. Hence, there is strong support evidence in the data in order to declare hypotheses 4 and 5 confirmed.

The control variable (company age) in Case 2, Case 3 and Case 4 was not significant from the regression results. It seems that the private and foreign enterprises or hotels are likely to build inter-firm relationship than public firms. This can because that private hotels owners tend to use social network and frequently communication each other in order to build the relationship among the tourism value chain. Moreover, an analysis of coefficients between trust and its antecedents (company characteristics, executive characteristics, use of formal institutions, use of social network, and communication) by adding control variables did not reveal any difference. These results confirmed the robustness of these relationships. Therefore, all hypotheses in the study had gotten strongly support from empirical results. 


\section{Discussions and Conclusions}

\subsection{Discussions}

The major distinction of the study is the construction of the comprehensive view about inter-firm trust and its antecedents. All five hypotheses of this research were supported. The first two hypotheses relate to the given factors that are characteristics of company and its executive. The later three reflect the role of the executives who involve in inter-firm relationships.

There are positive relationships between company characteristics, its executives and inter-firm trust. Trust theory has established that the superior competence of subjects based on its characteristics play a significant role in the development of trust in its partner (Doney \& Cannon, 1997; Ganesan, 1994; Kennedy et al., 2001; Mayer et al., 1995; Moorman et al., 1993; Zucker, 1986). The study, which covered a broad base of these characteristics, showed that these attributes did in fact relate to high level of inter-firm trust.

The empirical results found support for the relationship between the use of formal institutions and inter-firm trust. The use of formal institutions will shape partner toward commonly acceptable behavior and prevent them from opportunism. This finding supports the expectation of Nguyen and Rose (2009) and contrast significantly with the conclusion of Nguyen et al. (2005), which stated that "Vietnam has never developed the institutions of a market economy." The results reflect the development of Vietnamese market institutions in directing firm behavior and contributing to build trust among them as the result in general.

The active role of manager in building trust between partners can be seen through the strategy of using social network and actively communication. The findings, in line with several studies (Adobor, 2006; Cerri, 2012; Nguyen \& Rose, 2009), indicate that using social network is the main way to build inter-firm trust. Social network, particular informal third parties, helps target partners in learning each other. Moreover, active communication and business information sharing has been proven to be viable means of stimulating trust between firms. Trust naturally appears as a result of repeated personal interactions, information sharing, and communication between executives (Nguyen et al., 2005).

\subsection{Theoretical Contributions}

This study contributes to the literature on inter-firm trust and inter-firm relationships in two ways. First, the research emphasizes on both sides of trust: the fixed side and soft side (Nguyen \& Liem, 2013). By studying the impact of given factors, the role of manager, combining with the influence of environment, the study provides the comprehensive view of trust. With this view, company can develop trust intentionally based on changing its attributes, choosing its proper executives, as well as applying suitable strategy. Trust not only depends on given factors, but also depends on the way that executive interacts with its partner.

Second, the study enhances our knowledge on social exchange by confirming the positive links between the use of formal institutions and inter-firm trust. Formal institutions in Vietnam have been mentioned in previous studies (McMillan \& Woodruff, 1999; Nguyen et al., 2005; Nguyen \& Rose, 2009). The common share in these studies relates to the lack or the weakness of formal institutions in Vietnam. Even with recently article, Steer and Sen (2010) found that company has rarely used court as mechanism in its business activity. They think that courts are not considered as an effective mechanism in preventing opportunism. However, formal institutions in Vietnam have been developed and proven to have directly influenced firm's behavior in this study.

\subsection{Managerial Contributions}

Trust appears in both fixed and soft sides (mentioned by Nguyen \& Liem, 2013). For the soft side, the manager can intentionally build trust. The empirical results suggest that the manager can take advantage from the improved institutions to shape and prevent partner from opportunism. More importantly, in Vietnamese context, social network appears to be the most influence factor in directing inter-firm behavior and building trust (Nguyen \& Rose, 2009; Steer \& Sen, 2010). Therefore, by expanding their social network, the executive and its partner can learn each other. Further, sharing business information is the best way to demonstrate company's goodwill as well as the engaging in the inter-firm relationship.

For the fixed side, the company can demonstrate it superior competency not only from itself but also from its executives. It is hard and takes long time to level up the characteristics of a firm. However, company can facilitate inter-firm trust through its executive. By assigning the competent executive in inter-firm relationship, the company and its partner can build trust easily.

\section{References}

Adobor, H. (2005). Trust as sensemaking: The microdynamics of trust in interfirm alliances. Journal of Business 
Research, 58(3), 330-337. http://dx.doi.org/10.1177/1059601106294215

Adobor, H. (2006). Inter-firm collaboration: Configurations and dynamics. Competitiveness Review, 16(2), 122-134. http://dx.doi.org/10.1108/cr.2006.16.2.122

Armstrong, J. S., \& Overton, T. S. (1977). Estimating nonresponse bias in mail surveys. Journal of Marketing Research, 14, 396-402. http://dx.doi.org/10.2307/3150783

Anderson, E., \& Weitz, B. (1989). Determinants of continuity in conventional industrial channel dyads. Marketing Science, 8(4), 310-323. http://dx.doi.org/10.1287/mksc.8.4.310

Anderson, J. C., \& Narus, J. A. (1990). Model of distributor firm and manufacturer firm working partnerships. Journal of Marketing, 54(1), 42-58. http://dx.doi.org/10.2307/1252172

Aulakh, P. S., Kotabe, M., \& Sahay, A. (1996). Trust and Performance in Cross-Border Marketing Partnerships: A Behavioral Approach. Journal of International Business Studies, 27, 1005-1032. http://dx.doi.org/10.1057/palgrave.jibs.8490161

Bamford, J., Ernst, D., \& Gubini, D. G. (2004). Launching A World-class Joint Venture. Harvard Business Review, 82(2), 91-100.

Bhattacharya, R., Devinney, T. M., \& Pillutla, M. M. (1998). A Formal Model of Trust Based on Outcomes. Academy of Management Review, 23(3), 459-472. http://dx.doi.org/10.5465/AMR.1998.926621

Brislin, R. W. (1970). Back-translation for cross-cultural research. Journal of Cross-Cultural Psychology, 1(3), 83-93. http://dx.doi.org/10.1177/135910457000100301

Buchel, B. (2003). Managing Partner Relationships in Joint Ventures. MIT Sloan Management Review, 44, 91-95.

Cerri Shpëtim. (2012). Exploring factor affecting trust and relationship quality in a supply chain context. Journal of Business Studies Quarterly, 4(1), 74-90.

Coote, L. V., Forrest, E., \& Tam, T. W. (2003). An investigation into commitment in non-western industrial marketing relationships. Industrial Marketing Management, 32(7), 595-604. http://dx.doi.org/10.1016/S0019-8501(03)00017-8

Coulter, K. S., \& Coulter, R. A. (2002). Determinants of trust in a service provider: The moderating role of length of relationship. Journal of Services Marketing, 16(1), 35-50. http://dx.doi.org/10.1108/08876040210419406.

Curral, S. C., \& Inkpen, A. C. (2002). A multilevel approach to trust in joint ventures. Journal of International Business Studies, 33, 479-495. http://dx.doi.org/10.1057/palgrave.jibs.8491027

Doney, P. M., \& Cannon, J. P. (1997). An Examination of the Nature of Trust in Buy-Seller Relationships. Journal of Marketing, 61(2), 35-51. http://dx.doi.org/10.2307/1251829

Dyer, J. H., \& Chu, W. (2000). The Determinants of Trust in Supplier-automaker Relationships in the United States, Japan and Korea. Journal of International Business Studies, 31(2), 259-285. http://dx.doi.org/10.1057/palgrave.jibs.8490905

Fang, E., Palmatier, R. W., Scheer, L. K., \& Li, N. (2008). Trust at Different Organizational Levels. Journal of Marketing, 72, 80-98. http://dx.doi.org/10.1509/jmkg.72.2.80

Finkelstein, S., \& Hambrick, D. C (1990). Top management team tenure and organizational outcomes: The moderating role of managerial discretion. Administrative Science Quarterly, 35(3), 484-503. http://dx.doi.org/10.2307/2393314

Fornell, C., \& Larcker, D. F. (1981). Structural equation models with unobservable variables and measurement error. Journal of Marketing Research, 18, 39-50. http://dx.doi.org/10.2307/3150980

Ganesan, S., \& Hess, R. (1997). Dimensions and Levels of Trust: Implications for Commitment to a Relationship. Marketing Letters, 8, 439-448. http://dx.doi.org/10.1023/A:1007955514781

Gassenheimer, J. B., \& Manolis, C. (2001). The Influence of Product Customization and Supplier Selection on Future Intentions: The Mediating Effects of Salesperson and Organizational Trust. Journal of Managerial Issues, 13(4), 418-435.

Gill, H., Boies, K., Finegan, J. E., \& McNaly, J. (2005). Antecedent of trust: establishing a boundary condition for the relation between propensity to trust and intention to trust. Journal of Business and Psychology, 19(3), 
287-302. http://dx.doi.org/10.1007/s10869-004-2229-8

Hair, J. F., Black, W. C., Babin, B. J., \& Anderson, R. E. (2009). Multivariate data analysis (7th ed.). Prentice Hall.

Hardin, R. (1996). Trustworthiness. Ethics, 107(1), 26-42. http://dx.doi.org/10.1086/233695

Hoang, H., \& Antoncic, B. (2003). Network-based research in entrepreneurship: A critical review. Journal of Business Venturing, 18(2), 165-187. http://dx.doi.org/10.1016/S0883-9026(02)00081-2

Jiang, C. X., Chua, R. Ji, Kotabe, M., \& Murray, J. Y. (2011). Effects of cultural ethnicity, firm size, and firm age on senior executives' trust in their overseas business partners: Evidence from China. Journal of International Business Studies, 42, 1150-1173. http://dx.doi.org/10.1057/jibs.2011.35

Kennedy, M. S., Ferrell, L. K., \& LeClairb, D. T. (2001). Consumers' Trust of Salesperson and Manufacturer: An $\begin{array}{llllll}\text { Empirical Study. Journal of Business Research, 51(1), } & \text { 73-86. }\end{array}$ http://dx.doi.org/10.1016/S0148-2963(99)00039-9

Kwon, Ik. W., \& Suh, T. (2004). Factors Affecting the Level of Trust and Commitment in Supply Chain Relationships. Journal of Supply Chain Management, 40(1), 4-14. http://dx.doi.org/10.1111/j.1745-493X.2004.tb00165.x

Lee, D. J., Pae, J. H., \& Wong, Y. H. (2001). A model of close business relationship in China (guanxi). European Journal of Marketing, 35(1/2), 51-69. http://dx.doi.org/10.1108/03090560110363346

Lui, S. S., Ngo, H. Y., \& Hon, A. H. Y. (2006). Coercive Strategy in Interfirm Cooperation: Mediating Roles of Interpersonal and Interorganizational Trust. Journal of Business Research, 59(4), 466-474. http://dx.doi.org/10.1016/j.jbusres.2005.09.001

Mayer, R. C., Davis, J. H., \& Schoorman, F. D. (1995). An Integrative Model of Organizational Trust. The Academy of Management Review, 20(3), 709-734. http://dx.doi.org/10.5465/AMR.1995.9508080

Knight, J. (1992). Institutions and social conflict. Cambridge University Press.

McKnight, D. H., Cummings, L. L., \& Chervany, N. L. (1998). Initial Trust Formation in New Organizational Relationships. Academy of Management Review, 23(3), 473-490. http://dx.doi.org/10.5465/AMR.1998.926622

McMillan, J., \& Woodruff, C. (1999). Inter-firm relationships and informal credit in Vietnam. The Quarterly Journal of Economics, 114, 1285-1320. http://dx.doi.org/10.1162/003355399556278

Mohr, J., \& Spekman, R. (1994). Characteristics of partnership success: Partnership attributes, communication behaviour, and conflict resolution techniques. Strategic Management Journal, 15(2), 135-152. http://dx.doi.org/10.1002/smj.4250150205

Moorman, C., Deshpandé, R., \& Zaltman, G. (1993). Factors Affecting Trust in Market Research Relationships. Journal of Marketing, 57(1), 81-101. http://dx.doi.org/10.2307/1252059

Morgan, R. M., \& Hunt, S. D. (1994). The commitment-trust theory of relationship marketing. Journal of Marketing, 58(3), 20-38. http://dx.doi.org/10.2307/1252308

Nguyen, T. V., \& Rose, J. (2009). Building Trust-Evidence from Vietnamese Entrepreneurs. Journal of Business Venturing, 24, 165-182. http://dx.doi.org/10.1016/j.jbusvent.2008.03.004

Nguyen, P. N. (2011). Applying theory of reasoned action to explain inter-firm cooperation: Empirical evidence from Vietnamese enterprises. International Journal of Management \& Information Systems, 15(3), 61-81.

Nguyen, N. P., \& Liem, N. T. (2013). Inter-Firm Trust Production: Theoretical Perspectives. International Journal of Business and Management, 8(7), 46-54. http://dx.doi.org/10.5539/ijbm.v8n7p46

North, D. (1990). Institutions, institutional change and economic performance. Cambridge University Press, Cambridge, New Your.

Pak, Y. S., Ra, W., \& Park, Y. R. (2009). Understanding IJV Performance in A Learning and Conflict Mediated Context. International Business Review, 18, 470-480. http://dx.doi.org/10.1016/j.ibusrev.2009.07.006

Pesämaa, O., \& Hair, J. F. Jr. (2007). More than Friendship is Required: An Empirical Test of Cooperative Firm Strategies. Management Decision, 45(3), 602-615. http://dx.doi.org/10.1108/00251740710745142

Podsakoff, P., \& Organ, D. (1986). Self-reports in organizational research: Problems and prospects. Journal of Management, 12, 531-544. http://dx.doi.org 10.1177/014920638601200408 
Rotter, J. B. (1967). A New Scale for the Measurement of Interpersonal Trust. Journal of Personality, 35, 651-665. http://dx.doi.org/10.1111/j.1467-6494.1967.tb01454.x

Rousseau, D. M., Sitkin, S. B., Burt, R. S., \& Camerer, C. (1998). Introduction to special topic forum: Not so different after all: A cross-discipline view of trust. Academy of Management Review, 23, 393-404. http://dx.doi.org/10.5465/AMR.1998.926617

Sako, M., \& Helper, S. (1998). Determinants of Trust in Supplier Relations: Evidence from the Automotive Industry in Japan and the United States. Journal of Economic Behavior \& Organization, 34(3), 387-417. http://dx.doi.org/10.1016/S0167-2681(97)00082-6

Schumacker, R. E., \& Lomax, R. G. (2004). A beginner's guide to structural equation modeling (2nd ed.). Mahwah, NJ: Lawrence Erlbaum Associates.

Shapiro, D. L., Sheppard, B. H., \& Cheraskin, L. (1992). Business on a handshake. Negotiation Journal, 8 , 365-377. http://dx.doi.org/10.1111/j.1571-9979.1992.tb00679.x

Shinkle, G., \& Kriauciunas, A. (2010). Institution, size, and age in transition economics: Implications for export growth. Journal of International Business Studies, 41(2), 267-286. http://dx.doi.org 10.1057/jibs.2009.9

Steer, L., \& Sen, K. (2010). Formal and informal institutions in a transition economy: The case of Vietnam. World Development, 38, 1603-1615. http://dx.doi.org/10.1016/j.worlddev.2010.03.006

Svensson, G. (2001). Perceived trust towards suppliers and customers in supply chains of the Swedish automotive industry. International Journal of Physical Distribution \& Logistics Management, 31(9), 647-662. http://dx.doi.org/10.1108/09600030110408152

Sztompka, P. (2003). Trust. A Sociological Theory. Cambridge University Press.

Tuang, A., \& Stringer, C. (2008). Trust and commitment in Vietnam: The industrial distributor's perspective. International Journal of Emerging Markets, 3(4), 390-406. http://dx.doi.org/10.1108/17468800810906093

Venkatesh, V., Thong, J. I. L., \& Xu, X. (2012). Consumer acceptance and use of information technology: Extending the unified theory of acceptance and use of technology. MIS Quarterly, 36(1), 157-178.

Zaheer, A., McEvily, B., \& Perrone, V. (1998). Does Trust Matter? Exploring the Effects of Interorganizational and Interpersonal Trust on Performance. Organization Science, 9, 141-159. http://dx.doi.org/10.1287/orsc.9.2.141

Zucker, L. G. (1986). Production of Trust: Institutional Sources of Economic Structure, 1840-1920. In Staw, B. M., \& Cumming, L. L. (Eds.), Research in Organizational Behavior (pp. 53-111). JAI Press, Greenwich, CT.

Yamagishi, T., \& Yamagishi, M. (1994). Trust and commitment in the United States and Japan. Motivation and Emotion, 18, 129-165. http://dx.doi.org/10.1007/BF02249397

Young-Ybarra, C., \& Wiersema, M. (1999). Strategic flexibility in information technology alliances: The influence of transaction cost economics and social exchange theory. Organization Science, 10, 439-459. http://dx.doi.org/10.1287/orsc.10.4.439

\section{Copyrights}

Copyright for this article is retained by the author(s), with first publication rights granted to the journal.

This is an open-access article distributed under the terms and conditions of the Creative Commons Attribution license (http://creativecommons.org/licenses/by/3.0/). 